\title{
Anti-Diabetic Effects of Red Rose Flowers in Streptozotocin-Induced Diabetic Mice
}

\author{
Jae Eun Ju $\cdot$ Yong Hoon Joo $\cdot$ Namhyun Chung $\cdot$ Soo Yeon Chung $\cdot$ Sung Hee Han $\cdot$ Yong Kwon Lee
}

Received: 4 June 2014 / Accepted: 10 June 2014 / Published Online: 31 August 2014

(C) The Korean Society for Applied Biological Chemistry and Springer 2014

\begin{abstract}
Diabetes mellitus is a common chronic metabolic disease that is of increasing concern, because it frequently leads to complications such as cardiovascular diseases and cancer. Plants have been studied as a potential source for anti-diabetics to supplement dietary modifications, insulin, and other medications. The components of green tea polyphenols can be changed by processes such as browning. This processing method was applied to the red rose flower to determine whether the processed or nonprocessed rose flower has an anti-diabetic effect on the streptozotocininduced diabetic mouse. Aqueous extracts of processed and nonprocessed rose flowers were analyzed using liquid chromatography/ mass spectrometry. The results show that the polyphenol content decreased with browning. The hemoglobin Alc level, an indicator of long-term diabetes, in diabetic mice after administration of extracts of browned rose flowers for 24 and $48 \mathrm{~h}$ were lower than those after administration of extracts of non-browned rose flowers. Moreover, the activity of aspartate transaminase, which is often high in diabetic patients, was low in all groups treated with rose flowers, whether they were non-browned or browned. Taken together, these results indicate that extracts from red rose flowers
\end{abstract}

J. E. Ju and Y. H. Joo contributed equally.

J. E. Ju $\cdot$ Y. H. Joo $\cdot$ N. Chung $(\bowtie)$

College of Life Sciences \& Biotechnology, Korea University, Seoul 136713, Republic of Korea

E-mail: nchung@korea.ac.kr

S. Y. Chung

Industry-University Cooperation Foundation, Yuhan University, Bucheon 422-749, Republic of Korea

\section{S. H. Han}

Departments of Food and Nutrition, Yuhan University, Bucheon 422-749, Republic of Korea

\section{Y. K. Lee $(\bowtie)$}

Department of Culinary Art \& Food Service Management, Yuhan

University, Bucheon 422-749, Republic of Korea

E-mail: yklee@yuhan.ac.kr have long-term anti-diabetic effects, and that this effect is independent of the level of polyphenols in the extract.

Keywords anti-diabetic effect $\cdot$ hemoglobin Alc $\cdot$ plant browning $\cdot$ polyphenols $\cdot$ red rose flower

\section{Introduction}

Diabetes mellitus is a metabolic disease characterized by impaired control of blood glucose. According to a recent report, the prevalence of diabetes is anticipated to increase upto $11.4 \%$ by 2030 (Shaw et al., 2010). Because diabetes mellitus becomes a more common chronic disease, experiments to investigate more diverse clinical preventive measures are needed. Diabetes mellitus is classified into type 1 and type 2 (Inzucchi et al., 2010). In the present study, type 1 diabetes has been chosen as a model of diabetes mellitus. Many drugs have been developed to ease the symptoms of diabetes. In addition, various parts of plants have been studied as potential sources for anti-diabetics. Plants contain a variety of chemical compounds, including alkaloids, polysaccharides, terpenoids, and inorganic ions, which can be assessed for their potential to lessen the various symptoms of diabetes. For example, other plants such as Aloe vera, Capparis decidua, Citrullus colocynthis, and Eugenia uniflora have been reported to have antidiabetic activities (Grover et al., 2002).

Various forms of tea, such as green tea, oolong tea, and black tea, are commonly used beverages worldwide. These aqueous extracts are known to have many biological functions, including antioxidant, anticancer, and anti-diabetic activities (Al-Awadi and Gumaa KA, 1987). Interestingly, the chemical contents of tea, such as polyphenols, can be changed by processing. Green tea and their fermented forms, oolong and black tea, originate from the same plants, but the characteristics of their chemical components are quite different. For example, non-fermented green tea contains 
mainly catechins, which have many biological activities, as major chemical components. Whereas fermented teas mostly have oxidized theaflavin, which has a cholesterol-lowering effect, as well as catechins (Cooper, 2012). Flowering plants are often recognized as decorative plants. However, recently a few studies have shown that flowers contain numerous nutritional compounds such as sugars, polyphenols, proteins, and minerals (Jaeger et al., 2010). In the present experiment, both non-browned and browned flowers from the red rose were tested for anti-diabetic activities.

\section{Materials and Methods}

Chemicals. (-)-Catechin, (+)-epicatechin(EG), (-)-epicatechin gallate (ECG), (-)-epigallocatechin (EGC), (-)-epigallocatechin gallate (EGCG), quercetin, and rutin were purchased from SigmaAldrich (USA).

Extraction of red rose flower. Rosa multiflora var. platyphyllas were obtained from Mururang-Daraerang Co. (Korea). Dried rose flowers were homogenized and processed with or without browning for $48-96 \mathrm{~h}$ at $80^{\circ} \mathrm{C}$ under $84 \%$ humidity, which was maintained under supersaturated conditions with sodium chloride. Flower samples were extracted with deionized water at $80^{\circ} \mathrm{C}$ in a water bath for $15 \mathrm{~min}$. After centrifugation at $8,000 \times \mathrm{g}$ for $10 \mathrm{~min}$, the infusions were filtered with $0.22 \mu \mathrm{m}$ Millex-GV syringe filter unit (EMD Millipore, USA). The resulting extracts were freezedried and used after appropriate dilution.

Liquid chromatographic/mass spectrometry (LC/MS) analysis. Concentrations of various polyphenolic compounds were determined using a triple Quadrupole LC/MS system (Agilent 6430, Agilent Technology, USA). The column used was a Gemini ${ }^{\mathrm{TM}}$ C6-Phenyl $(2.1 \times 150 \mathrm{~mm}, 3.5 \mu \mathrm{m}$, Phenomenex, USA), and the flow rate was $0.2 \mu \mathrm{L} / \mathrm{min}$ using solvent A (acetonitrile) and solvent $\mathrm{B}$ ( $1 \%$ trifluoroacetic acid in water). The gradient was as follows: $0-10 \mathrm{~min}, 5 \% \mathrm{~A}$ (isocratic); $10-1 \mathrm{~min}, 100 \% \mathrm{~A}$ in $\mathrm{B}$ (isocratic); $11-4 \mathrm{~min}, 100-5 \% \mathrm{~A}$ in $\mathrm{B}$ (linear gradient); 14$20 \mathrm{~min}, 5 \% \mathrm{~A}$ (isocratic). The analyses were carried out using an electrospray (ESI) interface operating in negative ion mode under the following conditions: drying gas (nitrogen) flow, $4 \mathrm{~L} / \mathrm{min}$; nebulizer gas pressure, $60 \mathrm{psi}$; gas drying temperature, $350^{\circ} \mathrm{C}$; capillary voltage, $2500 \mathrm{~V}$; and fragmentor voltage, 90-110 V. A UV detector was used to detect rose polyphenols at $270 \mathrm{~nm}$.

Animal experiments. C57BL/6J male mice, aged 6 weeks, purchased from Central Lab Animal Inc. (Korea), were used in this experiment. The mice were acclimated for 10 days in polyethylene cages with free access to water and a $15 \%$ fat diet in a controlled environment $\left(20 \pm 2^{\circ} \mathrm{C}\right.$ and $60 \pm 10 \%$ relative humidity, with a $12 \mathrm{~h}$ light-dark cycle). Diabetes was induced by streptozotocin (STZ) treatment, which destroys the $\beta$-cells of the pancreas and induces type 1 diabetes (Goldberg et al., 2004). STZ solution was intraperitoneally injected at a dose of $70 \mathrm{mg} / \mathrm{kg}$ for 4 consecutive days beginning at 8 weeks of age. The mice were divided into five groups; water control group, non-browned rose extract group, 48 $\mathrm{h}$ browned rose group, $72 \mathrm{~h}$ browned rose group, and $96 \mathrm{~h}$ browned rose group. The mice were orally administered $200 \mu \mathrm{L}$ of the appropriate rose extract $\left(500 \mathrm{mg} / \mathrm{kg}\right.$ in $\left.\mathrm{dH}_{2} \mathrm{O}\right)$ once a day for 6 weeks. The body weights of the mice were measured at 3day intervals. The mice were sacrificed 26 days after the final rose flower or water feeding. Blood samples from the mice were collected by cardiac puncture after anesthesia.

Analysis of blood serum. The hemoglobin Alc level was measured with a mouse Hemoglobin Alc (HbAlc) Assay Kit (Crystal Chem, Inc. USA) using blood serum after separation from mouse blood by centrifugation at $8,000 \times \mathrm{g}$ for $15 \mathrm{~min}$. Glucose in blood was monitored every week for 26 days using OneTouch Ultra Blood Glucose Monitoring System (LifeScan, USA). The aspartate transaminase (AST) and alanine transaminase (ALT) levels in the serum were determined by EnzyChrom ${ }^{\mathrm{TM}}$ AST Assay Kit (Gentaur Molecular Products, Belgium) and EnzyChrom $^{\text {TM }}$ ALT Assay Kit (Gentaur Molecular Products), respectively.

\section{Results and Discussion}

The processing of green tea mainly involves steaming and roasting. This process could change the inherent components of tea (Cooper, 2012). This should also be applicable to the red rose flower. We hypothesized that the processing of the rose flower would influence its effects on diabetes and liver function. In the present study, the red rose flower was treated for up to $96 \mathrm{~h}$ under non-enzymatic browning conditions. (i.e., Maillard reaction) (Jaeger et al., 2010). Fresh rose flower contains polyphenols such as quercetin, catechin, rutin, and other phenolic compounds. The polyphenol content of browned rose flower decreased to undetectable levels within $48 \mathrm{~h}$ of browning, except for the quercetin content, which decreased by half in $48 \mathrm{~h}$ (Fig. 1). Thus, the trend of the loss of phenolic compounds during browning of rose flowers is almost the same as in green tea (Wang et al., 2000).

Consumption of tea plants has been reported as an effective measure for preventing and treating cancer, obesity, arthritis, and other diseases (Liu et al., 2008; Hasani-Ranjbar et al., 2009; Maki et al., 2009). The complication of diabetes is closely related to disorder of blood glucose control. The glucose level in blood must be reduced by tissue uptake and metabolism in order to maintain a stable blood glucose level. The short-term anti-diabetic efficacy of these plants was evaluated by a change in the level of blood glucose. To examine the effect of non-browned and browned rose flowers, extracts from those flowers were administered orally to STZ-induced diabetic mice. All flower extracts were considered to be harmless based on the fact that weight of the mice was not significantly changed during experiment. The extent of suppression of blood glucose levels 5 days post treatment were slightly lower in the groups treated with browned rose flowers than with fresh rose flowers, but no significance was observed thereafter (data not shown). However, a more reliable anti-diabetic effect can be 


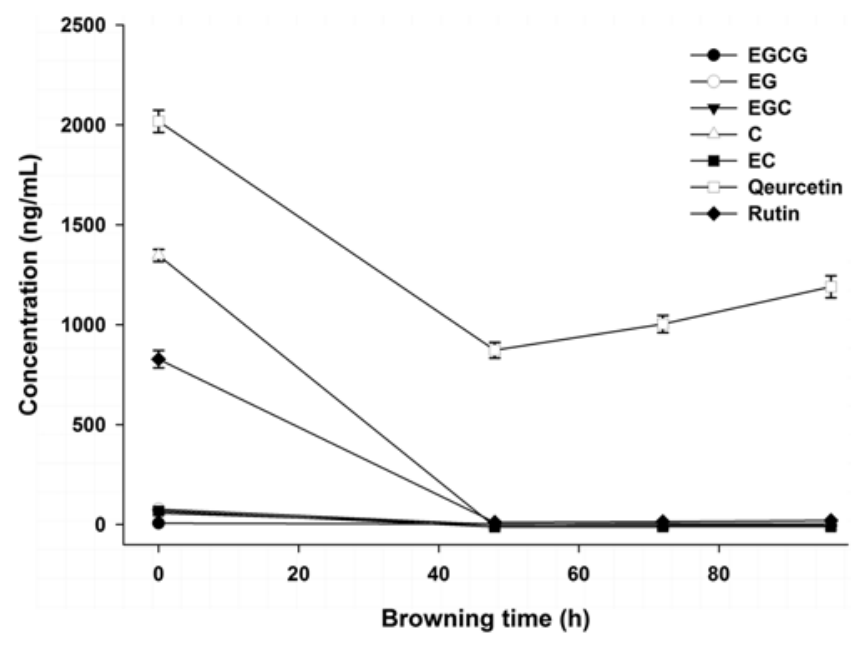

Fig. 1 Change in polyphenol contents of aqueous extracts of red rose flower with browning time. C; $(-)$-Catechin, EG; $(+)$-epicatechin, ECG; (-)-epicatechin gallate, EGC; (-)-epigallocatechin, EGCG; (-)epigallocatechin gallate.

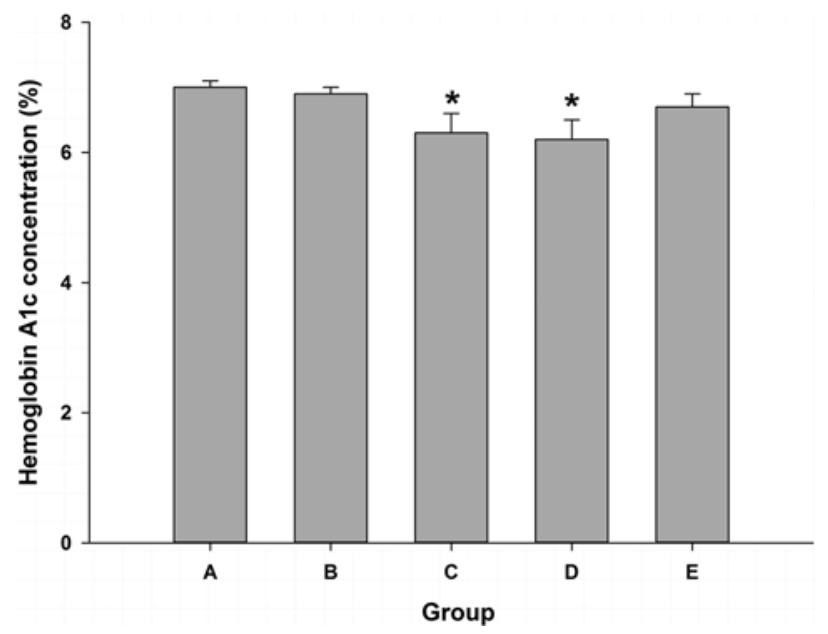

Fig. 2 Analysis of hemoglobin A1c levels in blood serum of streptozotocin-induced diabetic mice. The groups are as follows. A: diabetic mice that received water (control); $\mathrm{B}$ : diabetic mice that received extract of non-browned rose flower; $\mathrm{C}$ : diabetic mice that received extract of rose flower browned for $48 \mathrm{~h}$; D: diabetic mice that received extract of rose flower browned for $72 \mathrm{~h}$; E: diabetic mice that received extract of rose flower browned for $96 \mathrm{~h}$. $*=$ statistically significant difference from negative controls $(p<0.05)$.

observed by measuring the level of hemoglobin A1c in blood, which reflects the mean blood sugar level over weeks to months (Koenig et al., 1976). Hemoglobin A1c level was lower in mice given extracts from rose flowers browned for 48 and $72 \mathrm{~h}$, whereas mice given extracts from non-browned rose flowers or rose flowers browned for $96 \mathrm{~h}$ showed no decrease of the level (Fig. 2). These results imply that browning is necessary to produce an anti-diabetic effect, but browning for more than $72 \mathrm{~h}$ decreases the anti-diabetic effect.

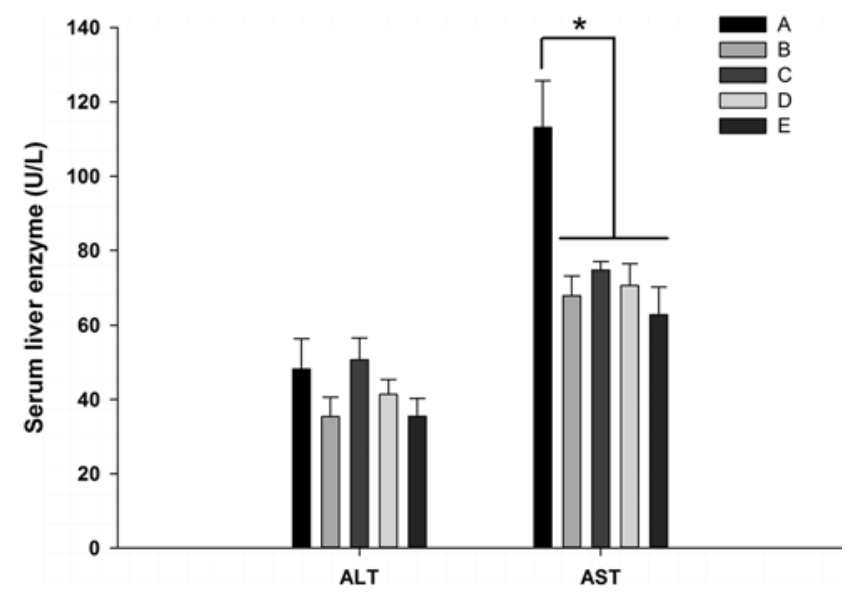

Fig. 3 Liver enzyme activities in blood serum of streptozotocin-induced diabetic mice. The groups are as follows. A: diabetic mice that received water (control); B: diabetic mice that received extract of non-browned rose flower; $\mathrm{C}$ : diabetic mice that received extract of rose flower browned for $48 \mathrm{~h}$; D: diabetic mice that received extract of rose flower browned for $72 \mathrm{~h}$; E: diabetic mice that received extract of rose flower browned for 96 h. $*=$ statistically significant difference from negative controls $(p$ $<0.05)$.

Another indication of an anti-diabetic effect can be the alanine transaminase (ALT) and aspartate transaminase (AST) levels in blood. These enzymes are indicators of liver metabolic function and related to the metabolism of glycogen in liver. Elevated levels of these transaminases in blood are frequently found in diabetic patients (Nannipieri et al., 2005). To observe the effect of nonbrowned and browned rose flowers on the diabetic mice, ALT and AST levels were measured after treatment (Fig. 3). The levels of ALT were lower in groups treated with extracts from nonbrowned and browned rose flowers, except for that from rose flowers browned for $48 \mathrm{~h}$; however, the overall difference was not statistically significant. On the other hand, the levels of AST were statistically lower in all groups treated with extracts from rose flowers than in the control group, whether they were non-browned or browned. We conclude that all the extracts of rose flowers have a significant effect on the recovery from liver damage in diabetic mice. Red rose flowers show high preference due to their attractive color and fragrance. We aimed to investigate the possibility that the garden red rose flower is a health-improving and functional food, especially for treatment of diabetes. Many studies on tea plants have been focused on phenolic compounds as a medicinal source. Non-browned rose flower contains significant levels of a variety of phenolic compounds, but the polyphenol content markedly decreased after browning (Fig. 1). This result contrasts with the suppression of the hemoglobin A1c levels by extracts from rose flowers browned for 24 and $48 \mathrm{~h}$. Thus, we also conclude that polyphenols of non-browned and browned rose flowers are not related to the anti-diabetic effect in STZ-induced diabetic mice. 
Acknowledgment This work was supported by Ministry for Food Agriculture, and Fisheries research funds (Grant no. 312007-03-1-SB040).

\section{References}

Al-Awadi FM and Gumaa KA (1987) Studies on the activity of individual plants of an antidiabetic plant mixture. Acta Diabetol 24, 37-41.

Cooper R (2012) Green tea and theanine: health benefits. Int J Food Sci Nutr 63, 90-7.

Goldberg IJ, Isaacs A, Sehayek E, Breslow JL, and Huang LS (2004) Effects of streptozotocin-induced diabetes in apolipoprotein AI deficient mice. Atherosclerosis 172, 47-53.

Grover JK, Yadav S, and Vats V (2002) Medicinal plants of India with antidiabetic potential. J Ethnopharmacol 81, 81-100.

Hasani-Ranjbar S, Larijani B, and Abdollahi M (2009) A systematic review of the potential herbal sources of future drugs effective in oxidant-related diseases. Inflamm Allergy Drug Targets 8, 2-10.

Inzucchi S, Bergenstal R, Fonseca V, Gregg E, Mayer-Davis B, Spollett G et al. (2010) Diagnosis and classification of diabetes mellitus. Diabetes Care 33, 62-9.
Jaeger H, Janositz A, and Knorr D (2010) The Maillard reaction and its control during food processing. The potential of emerging technologies. Pathol Biol 58, 207-13.

Koenig RJ, Peterson CM, Jones RL, Saudek C, Lehrman M, and Cerami A (1976) Correlation of glucose regulation and hemoglobin AIc in diabetes mellitus. $N$ Engl J Med 295, 417-20.

Liu J, Xing J, and Fei Y (2008) Green tea (Camellia sinensis) and cancer prevention: a systematic review of randomized trials and epidemiological studies. Chin Med 3, 12

Maki KC, Reeves MS, Farmer M, Yasunaga K, Matsuo N, Katsuragi Y et al. (2009) Green tea catechin consumption enhances exercise-induced abdominal fat loss in overweight and obese adults. J Nutr 139, 264-70.

Nannipieri M, Gonzales C, Baldi S, Posadas R, Williams K, Haffner SM et al. (2005) Liver enzymes, the metabolic syndrome, and incident diabetes: the Mexico City diabetes study. Diabetes Care 28, 1757-62.

Shaw JE, Sicree RA, and Zimmet PZ (2010) Global estimates of the prevalence of diabetes for 2010 and 2030. Diabetes Res Clin Pr 87, 4 14.

Wang LF, Kim DM, and Lee CY (2000) Effects of heat processing and storage on flavanols and sensory qualities of green tea beverage. $J \mathrm{Agr}$ Food Chem 48, 4227-32. 